Published January 2020

ENGLISH TEACHING AND LINGUISTICS

JOURNAL (ETLiJ)

ISSN 2716-0831 (online) | http://jurnal.umsu.ac.id/index.php/ETLiJ/index

\title{
The Effect Of Using Authentic Material As Media On The Students' Achievement In Listening
}

\author{
Evri Yenny Siregar ${ }^{1}$ \\ SDN 050742 Pangkalan Brandan \\ erinsiregar@gmail.com \\ Imelda Damayanti Manurung ${ }^{2}$ \\ Program Studi Pendidikan Bahasa Inggris \\ University of Muhammadiyah Sumatera Utara
}

\begin{tabular}{|c|c|}
\hline ARTICLE INFO & ABSTRACT \\
\hline $\begin{array}{l}\text { Received } \\
12 \text { Oktober } 2019 \\
\text { Revised } \\
16 \text { November } 2019 \\
\text { Accepted } \\
21 \text { Desember } 2019\end{array}$ & $\begin{array}{l}\text { The objective of this research is to investigate whether the use of } \\
\text { Authentic material as media has a significant effect to the students' } \\
\text { achievement in listening. The population of this research was the } \\
\text { eleven grade students of SMK Swasta Nurhasanah } 2 \text { Medan year } \\
2012 / 2013 \text {. The total number of population was } 50 \text { students in two } \\
\text { classes: class XI.AK. } 1 \text { was } 25 \text { students and class XI.AK. } 2 \text { was } 25 \\
\text { students, all the population were takes. So, there were } 50 \text { students as a }\end{array}$ \\
\hline $\begin{array}{l}\text { Keywords: } \\
\text { Authentic Material, } \\
\text { Media, } \\
\text { Listening }\end{array}$ & $\begin{array}{l}\text { sample. The sample was divided into two groups. The first group } \\
\text { consist of } 25 \text { students was taught by authentic material using news } \\
\text { items as media and the second group consist of } 25 \text { students was taught } \\
\text { by non authentic material using text book as media. This research used } \\
\text { quantitative method and experimental research. The instrument in } \\
\text { collecting data was essay test of complete the missing words. The } \\
\text { ability of students before giving authentic material as media is } 56 \% \text { or } \\
14 \text { students who were categorized as able and } 44 \% \text { or } 11 \text { students who } \\
\text { were categorized as unable. The ability of students after giving } \\
\text { authentic material as media is } 100 \% \text { or } 25 \text { students who were } \\
\text { categorized as able. The finding indicates that t-test }(3,72) \text { was higher } \\
\text { than t- table }(2,01) \text { with the level of significant } 0,05 \text { and the degree of } \\
\text { freedom (df) }=48 \text {. The findings showed that the hyporesearch } \\
\text { alternative (Ha) is accepted. It means that using authentic material as } \\
\text { media significantly effect to improve the students achievement in } \\
\text { Listening. }\end{array}$ \\
\hline
\end{tabular}

Cara Sitasi:

Siregar, E.Y., Manurung, I.D. (2019). The Effect of Using Authentic Material As Media on the Students' Achievement in Lisening. English Teaching and Linguistics Journal, Vol. 1, No. 1, pp $05-15$

\section{INTRODUCTION}

Language is by far the most important of the tools we use. It serves the purpose of communication with our fellow men, and without it no coordinated activity is possible. Finocchiaro (1985: in Syukri Nasution's book 2010: 3) language is a system of arbitrary 
vocal symbols, which permits all people in a given culture or other people who have learned the system of that culture, to communicate or to interact. In English language learning there are four skill, they are listening, reading, speaking and writing. Among four skills listening has essential function for successful communication, because without listening comprehension of spoken language, the communication cannot be run well. Listening is not only to listen but to comprehend what we have listened too.

The problem of the students includes first, acquisition results of learning by senses of vision greater than acquisition results of learning by senses of hearing. According Dale (1969: in Arsyad's book 2003: 9) said that "acquisition results of learning is 75\%, acquisition results of learning by senses of hearing is $13 \%$ and acquisition results of learning by other senses is $12 \%$ ".

Second, in grasping the sounds that created by the speaker, for example: the pronunciation the vocabulary of the speaker, automatically they must master and learn them. In other hand, if they just master a limited words, possibility we cannot convey our means and sometimes, it can be misunderstanding among us.

And in fact, many students are still hard to comprehend the text or pronounce vocabulary and they do not understand topic of the text or pronunciation of vocabulary, because sometimes they have problems to understand the sound of English words. The problem faced by the students in learning English, especially in listening English is the challenge for English teacher to enable for the students to use dictionary.

In this case, the teacher as a guide in the classroom must choose a good media to solve the problem of the students. According Hamalik (1986: in Arsyad's book 2003: 15) "The using of teaching media in learning process able evoke of new desires and interests, evoke of motivation and stimulus for learning, and influence the students' psychology". The using of teaching media in learning process also able make students for increase about understanding of material learning, presenting interest and actual data, and effectiveness of the learning process.

The teacher tries to motivate the students to pay attention in listening learning as important aspect so that they will make communication with another. And in this case the listeners' respond of the speaker conveyed is needed to know the ability of the students in listening learning. If there is no respond from the students (listener) automatically they cannot interpret the messages of the speaker conveyed.

Based on the above description, the researcher interested in analyzing a good media to solve the problem of the students and analysis what is the effect of using the media to the students' achievement in listening. The researcher choose authentic material as media. Authentic material media is taken from television programs, radio programs, interview or movie programs that are important to student. So, the researcher choose authentic material as media because to make student more interested and easy to listening learning, make results of learning by senses of vision and by senses of hearing is balanced, give information to other candidate of teacher about media of listening learning.

\section{MEDIA}

"Media" comes from the Latin which means "middle" "intermediary" or "introduction". According Gerlach \& Ely (1971: in Arsyad's book 2003: 3) media is human, material, or events that establish conditions that make students able to acquire knowledge, skill, or attitude. In this sense, media like teachers, textbooks, and school environment as a media. According Association of Education and Communication Technology (AECT) (1977: in Arsyad's book 2003: 3) media is the forms and channels used to convey messages or information. According Heinich (1982: in Arsyad's book 2003: 4) media is intermediaries to convey information from the source to the person receiving. So, programs of televisi, tape recorder, video, and picture is media of communication. 
According Sudjana and Rivai (1992: in Arsyad's book 2003: 25) the advantages of teaching media are: a) learning process more attract the attention of students so increase students' motivation; b) learning materials will more clearly so student better understand and achieve the learning material; c) teaching methods will be more varied so that students do not get bored; d) students can do more learning activities because students not only listen to teachers' explanations. Students can do activities, such as: observe, demonstrate, plays, etc.

\section{AUTHENTIC MATERIAL MEDIA}

According Baird (2004: 31) "There are two kinds of authentic material, they are: spoken and written". Kinds of spoken are TV commercials, films, news items, weather forecasts, airport and station announcement, radio talks, interviews, and debates. Kinds of written are: recipes, articles, train timetables, advertisements, brochures, poems, application forms, and instruction for use of equipment.

Based on the above description, authentic material as media oral and written material, such as TV commercials, films, news items, weather forecasts, radio programs, interviews, debates, advertisements, brochures, poems, application forms, and instruction for use of equipment. All materials use for English language teaching. It must related to real life because it make students to know about all events in the world, students more interest and motivated for English language learning. If we want to introduce authentic materials in language teaching, we need to classify them first, because some of them are suitable for the teaching of reading and some are effective when prepared for the teaching of listening and speaking. According to Gebhard (1996: 85), authentic materials can be classified into three categories:

a) Authentic Listening-Viewing Materials: TV commercials, quiz shows, cartoons, comedy shows, movies, professionally audio-taped short stories and novels, songs, and documentaries, films, news items, airport and station announcement, and radio talks.

b) Authentic Visual Materials: slides, photographs, paintings, children' artwork, stickfigure drawings, wordless street signs, pictures from magazine, postcard pictures, wordless picture books, and stamps.

c) Authentic Printed Materials: newspaper articles, movie advertisements, sports reports, restaurant menus, street signs, tourist information brochures, university catalogs, telephone books, maps, comic books, and bus schedules.

Using authentic materials can be a between the linguistic skills of the students and their professional knowledge goal. For this reason, authentic materials are becoming an appropriate teaching media to enable students in listening learning.

Authentic materials as a teaching media have some characteristics that differentiate with other teaching media:

a. Informative

All the issues or news in an authentic material are used to provide the students with the new information that can enrich their insight and horizon about what is happening in the society. Therefore, they are not only study English but also they are provided by a wide range information. So, students able follow the development of globalization era now days. b. Up to Date

Authentic materials are the media that are showing many new issues that are happening in the world. The hottest issues and topics are appeared every day in print and electric form. Thus, authentic materials keep the students informed what is happening in the world.

c. Learner's Level

Learner's language proficiency level and the linguistic demands of the listening text. Learner level is an important factor in selecting authentic listening materials. According to Driven (1981:57) said that "Spontaneously spoken language is too complex 
to be introduced in the classroom in the first stage of foreign language learning, but in the second or intermediate stage of foreign language learning, all the factors of the spontaneously spoken language come into action."

So for the lower level learners, we should provide easier materials such as the short headline type reports, audio and radio advertising, or short news broadcasts or children's songs.

For the intermediate levels, there is a wider range of choices. Four or five minutes TV or radio news reports, the slightly adopted movies, or even whole TV programs can be included. As for the advanced level students, they have learned the target language for years and have the ability of dealing with the possible difficulties with their linguistic competence and world knowledge. Teachers now can choose some political speeches, ceremonial formulae, gossip, family quarrels etc as the teaching materials. These materials are either very formal (ceremonial formulae, political speeches) or fairly informal (family quarrels), which are considered very difficult for foreign language learners.

\section{LISTENING}

Listening is a visible mental process, making it is difficult to describe, there are many definitions of listening in various fields. One theory suggests from pronunciation and grammar. Listeners must discriminate between sounds, understand vocabulary and grammatical structure, interpret stress and intentions retain and interpret this within the immediate as well as the larger socio-cultural context of utterance. Further, Rosts (2002: 2) defines "listening in broadest sense as a process of receiving what the speaker's actually says (receptive orientation) construction and reprinting meaning (constructive orientation) negotiating meaning with the speaker and responding (collaborative orientation) and creating through involvement, imagination and empathy (transformative orientation)."

According to the above statement, listening is a complex skill, ability to identify from language sound until sentence structure in order to be able to understand the massage, in the case listening runs in real activity trough some process where the listener must be active and creative in order to improve their listening ability.

Some aspects of listening are easier for the foreign language learner than others, because they know English well and these aspects can be a problem for the students in listening if they do not master English.

a. Hearing the Sounds

It is essential for the students to know the pronunciation of the words in English because the pronunciation of one with another words is differ and the differences of the pronunciation can be make difference in meaning. For example: "ship" and "sheep" or "fit" and "feet". As a teacher should train the students to practice their pronunciation very often by asking them to read text book. It is mean in order to they do not feel confuse if they make communication with another.

b. Understanding Intonation and Stress.

The stress, intonations and rhythm of spoken language is so varied. They are able to change the meaning of the spoken language utterances. The stress can show the spoken language meant because he gives a stress in his words. And intonation of spoken language often changes, sometimes intonation of spoken language is high in other said is fall. If the speaker is angry may be his intonation in speaking is high and if he feels sad automatically his intonation will fall down and rhythm of spoken language includes in tone of the speaker in speaking English. For example: soft, loud and so on. The ability of understanding intonations and stress can improve students' ability in listening the English text effectively, especially at learning process in the school. 
c. Coping with Redundancy and Noise

Noise occurs when information is not received by the listener because of interference. For example: a word or phrase is not understood because it is pronounced or misuse or the listener simply does not know it. Redundancy, of course often helps our problems because a listener may request a clarification by saying "sorry, i do not quite catch...", so the listener will not lose the input.

d. Predicting

Prediction is difficult for the foreign language learner for various reason. Intonation and stress patterns can play important part in supplying ground for certain kinds of expectations. If the listener can make a guess as to the sort of thing that is going to be said next, he will be much likely to perceive it and understand it well. He may ever be enable to do without it all together. If listener knows, how someone is going to finish his sentence, then the closing words, and he is able to "skim" start anticipating the next significant piece of information.

e. Understanding Colloquial Vocabulary

Much of the vocabulary used in colloquial speech may occur already between the foreign listener, but it does not mean that he is familiar with it, so the listener should learn the colloquial vocabulary because in conversation situation, speaker often uses it by learning it they can enrich the enrichment of their vocabulary and they will not lose something/ messages in conversation situation.

f. Fatigue

Anyone who has learn a foreign language how tiring, it is listening. And interpreting unfamiliar sounds, lexis and text for long stretches of time. Reading, writing and speaking also tiring, but at least as far as those activities are concerned, the listener can set his own pace and make breaks where he wish. So the listener (students) should avoid the fatigue feeling if they want to master English well.

g. Understanding Different Accents

Many foreign language learners who are used to the accents of their own teacher are surprised and dismayed, when they find difficulty in understanding someone else. What we can do is try to give them a reasonable familiarity with the most useful English accent, that is by saying the British and American standard variaties and then perhaps let them have a taste of some others simply to open their eyes to the possibilities and given them some practice. Based on the above description, accents of language is important because In linguistics, an accent is a manner of pronunciation peculiar to a particular individual, location, or national. An accent may identify the locality in which its speakers reside (a geographical or regional accent), the socioeconomic status of its speakers, their ethnicity, their caste or social class, their first language

h. Using Visual and Aural Environmental Clues

The students should use visual and aural environmental clues to increase their capability in listening English comprehension because many foreign language learners seem to lack the ability to use environmental clues to get the meaning of an imperfectly grasped phrase. The students who have misunderstood something because they are analyzing words in isolation and not linking them to the context or accompanying visual stimuli, for example: when the speaker says "come here" in spite of a gesture of invitation.

\section{LISTENING SKILL}

In developing listening skills, one deals with a much broader area than auditory discrimination of speech souds. Listening is involved in every facet of the curriculum, and 
the school is programmed in such a way that children's listening skill must be effective if learning is to take place. Listening is required for following directions, developing and expanding concepts, maintaining discipline, planing curricular activities, and the like. Listening is closely related to many reading behaviors, such as utilizing intonation patterns in reading, developing auditory memory, and processing language presented orally in stories or discussion.

There will be a great number of learning activities in the school that depend on listening. These include listening to recordings of stories, poetry, and songs, listening to the teacher read stories, and participating in speaking-listening situation. These activities involve the child in listening to and interpreting language units ranging from single sentences through paragraphs and stories. The learner is called upon to attend, process, retain, and respond to language stimuli.

Heilman, Blair and Rupley (1981: 99) says there are activities for developing listening skills, they are:

\section{a. Critical Listening}

Here the teacher reads shorts, descriptive passages, and the children are asked to identify of what is described. The descriptions the teacher reads can vary in length and complexity, depending on the muturity or age level of the groups. These types of exercises can help teachers discover which children can listen effectively (and which cannot) and which children are self-sufficient (and which are dependent on others).

\section{b. Story Periods}

Pratically all children can be held spellbound by a good story well told. When the teacher tells or reads stories, she plants the ideas in the children's minds that good listening is the key to enjoyment of the story and that print is meaningful. Equally important is the fact that she can stress a purpose for listening, whether for enjoyment, for information, for answers to specific questions, or for practice in social living.

\section{c. Following Directions}

This can be used either as a class exercise with small groups or with individual pupils. Several short commands are stated, and the child, or the group, is to execute them in the order given. The performance will reveal the ability to attend to oral directions and the ability to hold these in memory.

\section{d. Finishing the Story}

This provides practice in developing language skills in listening, in using imagination, in using language, and in expecting logic and meaning from the reading.

\section{e. Completing the Sentence.}

This is a variation of the above in which the child supplies a word which has been ommited.

\section{f. What Word Disagrees with the Pictures?}

While looking at a pictures, pupils listen to the teacher as she says a series of four words, one of which could not be logically associated with the picture. Children are then asked to identify the word that does not belong. This can be a challenging game, because children must observe closely, listen carefully, and remember the word while other stimuli are presented.

\section{g. Retelling a Story}

The teacher reads a story or passage to one group who then tells the story to children who have not heard it. This experience motivates children to be good listeners since they must pay attention and comprehend if they are to retell the story successfully. Also, the emphasis on communicating meaning is highlighted.

\section{h. Emphasizing Expression}


The teacher reads a sentence or short passage word by word, without inflection, then reads it with good expression. Pupils are lead to see that how a passage is read affects its interpretation.

\section{i. Silly Sayings}

Read the following or similar sentences one at a time. After each sentence, call on a volunteer to explain what is wrong with the sentence and how it might be changed to make sense.

\section{j. Listen and Do}

Prepare a series of commands or tasks. Explain that you will describe a task and will then call on a volunteer to carry it out. Children must listen carefully since they do not know ahead of time who will be called upon.

\section{k. Whisper a Sentence}

Whisper a sentence to a child who in turn whispers it to another child, continuing until four or five children have participated. The last child says the sentence aloud. Then determine what changes were made in the message. A number of groups or teams may participate at the same time using the same message.

\section{METHOD}

The research was conducted to the students at grade XI students of 2012/2013 SMK Swasta Nurhasanah 2 Medan, Jl. Garu 1 no 28, Kecamatan Medan Amplas. The reasons to choose this school as the location of the research because it is accessible in term of time found, and same research never conducted there.

The population of this research was the students at grade XI students of 2012/2013 SMK Swasta Nurhasanah 2 Medan, J1. Garu 1 no 28. Kecamatan Medan Amplas, Kota Medan. There are two classes XI.AK.1 consists of 25 students and XI.AK.2 consists of 25 students So, the total of population was 50 students.

The sample of this research was whole student consisting of 50 students that separated into two classes. Because the total of population was less than 100, so all the student could be made as sample. According to Arikunto (2006: 134) states that if the subject is less than 100 , it is better to take the whole subjects that comprised 50 students.

\section{DISCUSSIONS}

The data required in this study were obtained from the result of the test that had been given to the student. The first group as the experimental group and the second group as the control group.

As the research is an experimental one, so below are the scores from both experimental and control group.

Table 1. The Result of the Pre-Test and Post-Test in Experimental Group

\begin{tabular}{|c|c|c|c|}
\hline \multirow{2}{*}{ No } & \multirow{2}{*}{ Student's Initial } & \multicolumn{2}{|c|}{ Score } \\
\cline { 3 - 4 } & APS & Pre-test & Post-test \\
\hline 1 & ASM & 55 & 60 \\
\hline 2 & AD & 55 & 60 \\
\hline 3 & AJ & 55 & 65 \\
\hline 4 & AS & 55 & 65 \\
\hline 5 & INM & 55 & 65 \\
\hline 6 & RS & 55 & 70 \\
\hline 7 & SJ & 55 & 70 \\
\hline 8 & AK & 65 & 70 \\
\hline 9 & DRS & 55 & 70 \\
\hline 10 & KL & 55 & 75 \\
\hline 11 & & \multicolumn{2}{|c}{} \\
\hline
\end{tabular}




\begin{tabular}{|l|c|c|c|}
\hline 12 & WI & 60 & 75 \\
\hline 13 & AAS & 55 & 75 \\
\hline 14 & DSJ & 65 & 75 \\
\hline 15 & HN & 65 & 75 \\
\hline 16 & WC & 65 & 75 \\
\hline 17 & NF & 70 & 80 \\
\hline 18 & PR & 70 & 80 \\
\hline 19 & WR & 75 & 80 \\
\hline 20 & NK & 75 & 85 \\
\hline 21 & RP & 75 & 85 \\
\hline 22 & NH & 70 & 85 \\
\hline 23 & NP & 70 & 90 \\
\hline 24 & HS & 75 & 90 \\
\hline 25 & TS & 75 & 90 \\
\hline
\end{tabular}

Table III The students' Ability in Listening after Giving Authentic Material as Media

\begin{tabular}{|c|c|c|c|c|}
\hline No & Student's Initial & $\begin{array}{c}\text { Quantitative } \\
\text { ability }\end{array}$ & $\begin{array}{c}\text { Quantitative } \\
\text { ability }\end{array}$ & Ability \\
\hline 1 & APS & 60 & Good & Able \\
\hline 2 & ASM & 60 & Good & Able \\
\hline 3 & AD & 65 & Good & Able \\
\hline 4 & AJ & 65 & Good & Able \\
\hline 5 & AS & 65 & Good & Able \\
\hline 6 & INM & 70 & Good & Able \\
\hline 7 & RS & 70 & Good & Able \\
\hline 8 & SJ & 70 & Good & Able \\
\hline 9 & AK & 75 & Good & Able \\
\hline 10 & DRS & 75 & Good & Able \\
\hline 11 & KL & 75 & Good & Able \\
\hline 12 & WI & 75 & Good & Able \\
\hline 13 & AAS & 75 & Good & Able \\
\hline 14 & DSJ & 75 & Good & Able \\
\hline 15 & HN & 75 & Good & Able \\
\hline 16 & WC & 80 & Very good & Able \\
\hline 17 & NF & 80 & Very good & Able \\
\hline 18 & PR & 80 & Very good & Able \\
\hline 19 & WR & 85 & Very good & Able \\
\hline 20 & NK & 85 & Very good & Able \\
\hline 21 & RP & 85 & Very good & Able \\
\hline 22 & NH & 90 & Very good & Able \\
\hline 23 & NP & 90 & Very good & Able \\
\hline 24 & HS & Very good & Able \\
\hline 25 & TS & & \\
\hline & & & & \\
\hline
\end{tabular}

From the table above, the researcher can explain that students' ability in listening after giving authentic material as media concludes that there were 9 students who were categorized as very good, and there were 16 students who were categorized as good, in other word 25 students who were categorized able. 
From the result obtained above, researcher can see that there are 25 students who were categorized as able in the students' ability in listening after giving authentic material as media. The whole percentage can be computed by using Arikunto's formula (2010:245)

$$
\begin{aligned}
& \mathrm{Q}=\frac{x}{y} \times 100 \% \\
& \text { Where: } \\
& \mathrm{Q}=\text { wanted percentage } \\
& \mathrm{X}=\text { able/unable of students } \\
& \mathrm{Y}=\text { the number students } \\
& \mathrm{Q}=\frac{25}{25} \times 100 \%=100 \% \\
& \mathrm{Q}=100 \% \text { (Able) }
\end{aligned}
$$

From the calculating above, students' ability in listening after giving authentic material as media that the students who were categorized as able 25 students' or $100 \%$.

\begin{tabular}{|c|c|c|c|c|c|}
\hline No & Student's Initial & $\begin{array}{c}\text { Pre-test } \\
\left(\mathrm{x}_{1}\right)\end{array}$ & $\begin{array}{c}\text { Post-test } \\
\left(\mathrm{x}_{2}\right)\end{array}$ & $\mathbf{x}_{2}-\mathbf{x}_{1}(x)$ & $\mathbf{x}^{2}$ \\
\hline 1 & APS & 45 & 60 & 15 & 225 \\
\hline 2 & ASM & 50 & 60 & 10 & 100 \\
\hline 3 & $\mathrm{AD}$ & 55 & 65 & 10 & 100 \\
\hline 4 & $\mathrm{AJ}$ & 55 & 65 & 10 & 100 \\
\hline 5 & $\mathrm{AS}$ & 55 & 65 & 10 & 100 \\
\hline 6 & INM & 55 & 70 & 15 & 225 \\
\hline 7 & $\mathrm{RS}$ & 55 & 70 & 15 & 225 \\
\hline 8 & SJ & 55 & 70 & 15 & 225 \\
\hline 9 & $\mathrm{AK}$ & 65 & 70 & 5 & 25 \\
\hline 10 & DRS & 55 & 75 & 20 & 400 \\
\hline 11 & $\mathrm{KL}$ & 55 & 75 & 20 & 400 \\
\hline 12 & WI & 60 & 75 & 15 & 225 \\
\hline 13 & AAS & 55 & 75 & 20 & 400 \\
\hline 14 & DSJ & 65 & 75 & 10 & 100 \\
\hline 15 & $\mathrm{HN}$ & 65 & 75 & 10 & 100 \\
\hline 16 & $\mathrm{WC}$ & 65 & 75 & 10 & 100 \\
\hline 17 & NF & 70 & 80 & 10 & 100 \\
\hline 18 & PR & 70 & 80 & 10 & 100 \\
\hline 19 & WR & 75 & 80 & 5 & 25 \\
\hline 20 & $\mathrm{NK}$ & 75 & 85 & 10 & 100 \\
\hline 21 & $\mathrm{RP}$ & 75 & 85 & 10 & 100 \\
\hline 22 & $\mathrm{NH}$ & 70 & 85 & 15 & 225 \\
\hline 23 & NP & 70 & 90 & 20 & 400 \\
\hline 24 & $\mathrm{HS}$ & 75 & 90 & 15 & 225 \\
\hline 25 & $\mathrm{TS}$ & 75 & 90 & 15 & 225 \\
\hline
\end{tabular}
From the data obtained, it may conclude that students of SMK Swasta Nurhasanah 2 had increase ability in listening after giving authentic material as media.

In arranging the correct answer of the students into table 4.5, the researcher made a tally to the number of the students' score that fall into each group and to write the score in column of frequency.

Table 2. The Different Score Between Pre-Test and Post-Test of Experimental Group 


\begin{tabular}{|l|l|l|l|l|l|}
\hline & & & $\sum \mathrm{x}=320$ & $\sum \mathrm{x}^{2}=4550$ \\
\hline
\end{tabular}

Based on the table 4.7 above, the researcher found that the total score of the students were 4550 . The mean score are calculated as the following.

$$
\begin{aligned}
\mathrm{Mx} & =\frac{\sum x}{N x} \\
& =\frac{320}{25} \\
& =12,8
\end{aligned}
$$
following

Based on the table 4.7 above the number of deviation score are calculated as the

$$
\begin{aligned}
\sum \mathrm{X}^{2} & =\sum \mathrm{x}^{2}-\frac{\left(\sum x\right)^{2}}{N} \\
& =4550-\frac{(320)^{2}}{25} \\
& =4550-\frac{(102400)}{25} \\
& =4550-4096 \\
& =454
\end{aligned}
$$

\section{CONCLUSIONS}

Having analyzed the data, conclusions are drawn as the following.

a) The ability of students before giving authentic material as media is 14 students or $56 \%$ who were categorized as able and 11 students or $44 \%$ who were categorized as unable.

b) The ability of students after giving authentic material as media is 25 students or $100 \%$ who were categorized as able.

c) Result of t-test is 3,72 and t-table is 2,01 ( $\mathrm{t}$-test $>\mathrm{t}$-table, 3,72 >2,01). It means that Ho is rejected and $\mathrm{Ha}$ is accepted. There is the effect of using authentic material as media on the students' achievement in listening.

d) From the data obtained it is seen that the result of authentic material as media to the students at grade XI students of 2012/2013 SMK Swasta Nurhasanah 2 Medan is higher than without using the authentic material as media. It means that the authentic material as media is significant to be used in improving the students' achievement in listening.

e) Authentic material as media make the students more motivated and interested to learn of listening. Also, students obtain information about events in the world so that students have an intrinsic educational value.

\section{REFERENCES}

Arikunto, Suharsimi. 2006. Prosedure Penelitian suatu pendekatan praktek. Jakarta: Rineka Cipta.

Arsyad, Azhar. 2003. Media Pembelajaran (Edisi Kesatu). Jakarta: Raja Grafindo Persada.

Brown, H, Doughlas. 1983. Principles of Language Learning and Teaching. (Fourth edition) London: Longman Group.

Buehl, D. 1995. Classroom Strategies for Interactive Learning. Wiconsin State Reading Association.

Heilman, Blair \& Rupley. 1981. Principles and Practices of Teaching Reading. (5th Edition) United States of America: Charles E. Merrill Publishing Co.

Nasution, Habib Syukri. 2010. Models of Grammar. Medan: Unpublished. 
Rost, Michael. 2002. Teaching and Researching Listening. (First Published): United Kingdom London.

Ur, Penny. 1984. Teaching Listening Comprehension. New York: Cambridge University Press.

Wilson, Edward. 2001. Writing and Grammar Communication in Action. (Platinum level): United States of America: Prentice Hall 